\title{
SOME PROBLEMS WITH TAXPAYER-FUNDED POLITICAL CAMPAIGNS
}

\author{
BRADLEY A. SMITH ${ }^{\dagger}$
}

\section{INTRODUCTION}

If one were trying to identify the world's healthiest democracy, the United States-with its long history of peaceful transitions of power, independent judiciary, sound record in human rights, expansive personal liberties, low inflation and unemployment, balanced government budgets, high standard of living, and relatively low taxes-would seem as good a candidate as any. Despite this, for literally decades we have been bombarded with complaints and warnings that this democracy was fundamentally unhealthy due to its reliance on private funds to finance political campaigns. Given the long-term record though, I think it prudent to presume that we ought to retain our traditional, private system of campaign finance, and that a high burden of proof should be placed on those proposing radical change.

When all is said and done, the indictment of private financing of campaigns rests on two arguments: it violates equality and fosters corruption. The system is unequal because not every citizen can give the same amount and because not every candidate or party can raise the same amount. They lack "equal" influence. It is "corrupt" because officeholders might feel beholden either to those who gave them money in the last election or to those who might give them money in future elections. These officeholders will thus lose the ability to act freely in carrying out their duties: they are subject to "undue influence."

For these reasons, twentieth-century America has witnessed a steadily expanding set of rules and regulations aimed at controlling the raising and spending of private campaign funds. But these efforts to regulate the private system of campaign finance have failed to accomplish their objectives, in part due to mistaken assumptions about the effects of money in politics, in part due to poorly designed legislation, and in part due to the role of the federal courts, which have

$\dagger$ Professor of Law, Capital University Law School. Thanks to Joel Gora for comments, and to Jennifer Goaziou for research assistance. 
struck down many aspects of regulation on First Amendment grounds. In short, regulating the private campaign finance system has, so far, been a flop. Law has its limits.

Frustration with the failure of regulation to cure the alleged evils of a private finance system have contributed to intellectual support for financing all campaigns with tax dollars. Though this is usually called "public" funding, that term is a misnomer. Campaigns are funded by the public now-by hundreds of thousands, even millions of citizens who make voluntary contributions to various candidates and organizations. What is euphemistically called "public" funding actually means "government" funded campaigns, or "tax" funding of campaigns, and I will address it as such. Government-funded campaigns are attractive because they can potentially take monetary inequality out of the equation, and because, by eliminating the need for candidates to rely on private donors, they can free officeholders to ignore the wishes of these donors, presumably to act in accordance with the individual officeholder's own conception of the public good.

Part I of this Article addresses some of the difficult issues in designing a system of government financing, in the process pointing out some often overlooked advantages to a private finance system. Part II reexamines the more fundamental justifications behind the push for tax financing-the questions of equality and corruption. Part III questions whether, even if all of these concerns are addressed, we will actually accomplish anything by extending tax financing to congressional and senatorial races.

\section{EASIER SAID THAN DONE: SOME DIFFICULT ISSUES FOR GOVERNMENT FINANCING}

To say that one favors government financing of campaigns is a bit like saying that one enjoys sports. Are we talking football? Kayaking? Downhill skiing? Ballroom dancing? Chess? The options are endless. Many people may favor government financing in principle, but oppose many, or even most, particular plans for government financing. Say, for example, one proposed a government financing plan providing that incumbents would receive twenty times the amount of money as challengers-I think it would have little support. ${ }^{1}$ Thus, let me be-

${ }^{1}$ One can argue that we already have a system of government financing that substantially favors incumbents, in the form of franking privileges, free web sites, paid time off to campaign, and so on, so perhaps this suggestion is not so far fetched. See Jamin Raskin \& John Bonifaz, Equal Protection and the Wealth Primary, II YALE L. \& POL'Y REV. 273, 289-91 (1993) (estimating the political self-subsidy of congressional 
gin not by criticizing government financing, but by considering a few criteria by which any campaign finance system ought to be measured, and compare how well government-financed plans generally fulfill these criteria relative to private finance schemes.

Here are my proposed criteria: ${ }^{2}$

Administrability: First, a system of campaign finance should be easy to administer.

Flexibility: Second, it should be flexible-able to adapt quickly to changing political environments, new technologies, and evolving campaign techniques.

Opportunity: Third, it should, if not necessarily foster more candidacies and entries into politics by political newcomers, at least not overly discourage such challenges.

Competitiveness. Fourth, it should, if not necessarily promote more competitive races, at least not overly insulate incumbents from challenge.

Communication: Finally, it should provide candidates with adequate funds to communicate with and educate voters.

For now, I will leave off of the list what are arguably the two most important criteria: the system should promote equality, and the system should insulate legislators from the influence of money (the "corruption" thesis). These I will take up in Part II. Readers who consider those to be the juicy questions in this debate can skip ahead. As for the five goals listed above, I do not know that this is by any means an exhaustive list, but it is certainly enough to get us started, and I think

incumbents to be $\$ 200,000$ during a two-year period). At the same time, there must be many people generally opposed to government financing who would, nonetheless, support the right plan for government financing. I suspect that this group is much smaller, however, because so much of the opposition to government financing is ideologically based. There are many who have a blanket objection to any government financing of campaigns as inherently beyond the scope of either good government, the Constitution, or both.

${ }^{2}$ These criteria, including equality and insulating legislators from the effect of money, are inclusive of Professor Briffault's three criteria. See Richard Briffault, Public Funding and Democratic Elections, 148 U. PA. L. REv. 563, 563 (1999). Professor Briffault elaborates on his criteria at some length and there is little in that portion of his discussion with which I would disagree. My own take on the question of voter equality, besides the discussion that follows, see infra Part II, is best explored in Bradley A. Smith, Money Talks: Speech, Comuption, Equality, and Campaign Finance, 86 GEO. L.J. 45, 88-98 (1997). Because this Article is based on a resolution which I interpret as being more focused on corruption, I have not addressed the equality issues here beyond describing my general take of the dividing line between me and those with whom I disagree. My disagreements with Professor Briffault on the question of corruption are reasonably well articulated in this Article. 
that most of these goals are relatively non-controversial. Although there are potential advantages for government-financed systems in meeting some of these criteria, in none of the five criteria listed above is it at all clear that government-financed systems are preferable to private ones.

\section{A. Administrability}

Campaign finance regulation creates compliance costs, both for government and for private political actors. Many systems will require substantial government resources to be devoted to monitoring and enforcement. A system that is too complex can create significant administrative, compliance, and funding difficulties for candidates, and this burden is likely to weigh heaviest on those candidates and groups which are new to political wars.

When it comes to ease of administration, no system can beat that of a private, unregulated system of funding, such as existed in all parts of the United States until very late in the nineteenth century, when laws regulating campaign finance first appeared. A completely unregulated system of campaign finance requires no government monitoring, auditing, or enforcement. There need be no federal agency of any kind entrusted with regulating the system. ${ }^{4}$ Similarly, on the candidate side there is no need to devote resources to compliance, and recordkeeping can be done with the needs of the candidate, rather than government monitors, foremost in mind. Against a baseline of unregulated private finance, extending government financing to congressional races loses the test on ease of administration every time.

We do not, however, have an unregulated system of private finance, but rather one that, at the federal level, is quite heavily regulated. It is unlikely that all regulation will end anytime soon; at a minimum, disclosure of private campaign contributions seems here to stay for the foreseeable future. ${ }^{5}$ Thus, a system of government financ-

${ }^{3}$ See Bradley A. Smith, Faully Assumptions and Undemocratic Consequences of Campaign Finance Reform, 105 YALE L.J. 1049, 1082-83 (1996) (arguing that regulations hurt political novices because they do not have the experience to comply with and interpret the law).

'This is not to say that there would not be routine law enforcement agencies engaged in prevention of bribery, blackmail, and other crimes that happen to take place in the context of political campaigns.

${ }^{5}$ But see McIntyre v. Ohio Elections Comm'n, 514 U.S. 334 (1995) (upholding the right to engage in anonymous speech on non-candidate-specific political issues); Amicus Guriae Brief of Gun Owners of America, Nixon v. Shrink Mo. Gov't PAC, 1999 WL 374576, at *25-*29 (U.S. cert. granted Jan. 25, 1999) (No. 98-963) (arguing that forced 
ing of congressional campaigns may actually reduce administrative costs from their current levels, though probably not to the level they would be in a deregulated system. From a government perspective, for example, the Federal Election Commission ("FEC") devotes far fewer resources to administration of the federal presidential campaign fund than to enforcement, audits, and disclosure. ${ }^{6}$ At the congressional level, the lion's share of those enforcement, auditing, and disclosure costs are incurred because the system relies on regulated private financing. If a government financing system were established that succeeded in gaining the participation of most congressional candidates, and were sufficiently simple to administer, it might lower government administrative costs. Moreover, it might actually lower costs for candidates as well, particularly if it succeeded in getting candidates out of the time-consuming and expensive fundraising business altogether.

Coming up with such a simple system is not so easy. For one thing, the Constitution, as correctly interpreted in Buckley v. Valeo, prevents the government from simply requiring all candidates to take public funds and limiting candidates' private spending. Thus candidates must be drawn into, as this resolution puts it, "optional public financing" and "voluntary spending limits." This could probably be done with ease if we were willing to fund campaigns adequately from the government till. We could provide, for example, a major party Senate nominee in California with $\$ 30$ million for the general election, a Senate nominee in Ohio with $\$ 8$ million, or a House nominee in any district with $\$ 2$ million or more. If we did, and such amounts were indexed for inflation, I suspect that most candidates would accept the government subsidy and the accompanying spending limit. Money, after all, has diminishing returns, and beyond the type of spending levels suggested above additional spending will not be expected to translate into many votes, if any. Candidates would probably find it worthwhile to take the money, accept the spending cap, and devote time to activities other than fundraising.

disclosure of campaign contributions violates the First Amendment).

${ }^{6}$ See FEC FY 2000 Budget Request (last modified Sept. 22, 1999) <http://www.fec. gov/pages/budcont.htm> (allocating $2 \%$ of budget to campaign fund administration while over $75 \%$ goes to enforcement, disclosure, and audits).

724 U.S. 1,58 (1976).

8 Only 11 House candidates took in more than $\$ 2$ million in the 1997-1998 election cycle, and only 39 topped $\$ 1.5$ million. See 1997-98, Top 50 House-Receipts (visited Sept. 10, 1999) <http://www.fec.gov/press/hserec98.htm> (listing candidate fundraising totals). 
The problem is that we are not inclined to provide government financing at such lavish levels. For example, Annelise Anderson has estimated the cost of a reasonable communications program for a presidential campaign to be at least $\$ 600,000,000$. ' We presently provide major party presidential nominees with less than $\$ 65$ million for the general election campaign. Yet virtually all "reform" measures suggest that we should lower, rather than increase, spending.

When subsidies are set too low, many candidates will be reluctant to join voluntary government financing schemes, figuring that they can raise more money and run a more effective campaign on private contributions. To provide incentives for candidates to opt-in despite low funding levels, many proposals for government funding include complicated provisions that increase administrative costs and can hamper grassroots candidacies. "Until "reformers" are willing to do away with such complicated and generally punitive trigger mechanisms and provide true incentives to take the public funds, it is likely that most proposals for government funding will increase administrative costs beyond those involved in the present system of regulated private financing, and far beyond those in an unregulated, or at least substantially deregulated, system of campaign finance.

\section{B. Flexibility}

A finance system should be flexible. Politics-in terms of issues, personalities, technologies, and tactics-is a rapidly changing field. Magazines such as Campaigns and Elections now exist for the purpose of keeping campaign managers and tacticians up to date on the latest developments in campaigning. A system that is geared to regulate or subsidize the last campaign may "distort" politics, and in particular runs the danger of "locking in" certain parties or candidates."

9 See ANNEIISE ANDERSON, POLITICAI MONEY: THE NEW Promitition 7-8 (1997). The figure is based on a campaign including: enough 30-second ads on network, cable, and local television in major media markets to reach most adults 10 times each; three to four 30-minute cable "Fireside Chats"; radio ads attempting to reach listeners in major radio markets five times each, one to two full page ads in every major newspaper in the country; two pieces of direct mail sent to each potential voter; a videocassette on the candidate sent to each household; and traditional billboards, buttons, and bumper stickers. Id.

${ }^{10}$ See, e.g., Gable v. Patton, 142 F.3d 940, $947-49$ (6th Cir. 1998), cert. denied, 119 S. Ct. 1112 (1999) (discussing the extent of the financial pressure Kentucky's campaign finance scheme puts on all candidates to participate).

"For example, ossified campaign finance laws, along with many other practices, helped to lock in a Democratic majority in the U.S. House in the 1970s and 1980s. See 
Unfortunately, government is notoriously slow at adjusting to changing realities. For example, not until 1999 did the FEC allow campaign contributions made on-line via credit cards to count toward federal matching funds in the presidential race, ${ }^{12}$ or allow electronic mail to be used to obtain payroll deductions for employee contributions to company political action committees ("PACs"). ${ }^{13}$ Yet in this area the FEC has actually acted with relative speed-much faster than Congress, for example, which has passed no legislation to clarify whether or not it believes that the Federal Election Campaign Act ("FECA") applies to certain internet communications. Similarly, Congress's 1974 enactment of a $\$ 1000$ contribution limit has never been adjusted, even though that limit has been eroded by inflation. So bad is Congress's inertia that proponents of reforming that limit are now urging the courts to step in to address the problem. ${ }^{14}$

Political practices often evolve specifically in response to, and to avoid the reach of, federal regulation. Long before passage of FECA, unions created "political action committees" to avoid the ban on union contributions and gain an advantage for Democrats over Republicans. ${ }^{15}$ Over the past twenty years we have seen the rise of independent expenditures and bundling, followed by the current rise in the importance of "soft money" and "issue advocacy." Such tactics are used to garner electoral advantages for particular interests. ${ }^{16}$ Regulation has often prevented opponents from responding quickly. ${ }^{17}$ Sim-

LARRY J. SABATO \& GLENN R. Simpson, DirTy LITTLE SECRETS: THE PERSISTENCE of CORRUPTION IN AMERICAN POLITICS 49-57 (1996) (discussing the importance of franking, redistricting, campaign contributions, and committee structures to solidifying the democratic majority in the House).

${ }^{12}$ See Advisory Opinion for Bill Bradley for President, Inc., 1999 WL 397749, at *4*5 (Federal Election Comm'n 1999).

${ }^{13}$ See Advisory Opinion for Nat'l Rural Letter Carriers' Ass'n, 1999 WL 300773, at *4-5 (Federal Election Comm'n 1999).

${ }^{14}$ See Amicus Curiae Brief of Senator Mitch McConnell, Nixon v. Shrink Mo. Gov't PAC, 1999 WL 367218, at *14-17 (U.S. cert. granted Jan. 25, 1999) (No. 98-963) (arguing that Buckley's authorization of a $\$ 1000$ limit on campaign contributions is so low that it now represents a clear impediment to running a campaign).

${ }^{15}$ See SABATO \& SIMPSON, supra note 11 , at $50-53$ (noting that the first political action committee was created by the Congress of Industrial Organizations, and it threw its support behind Democratic candidates, as did its successor).

${ }^{16}$ See, e.g., id. at $54-55$ (describing how such tactics have been used by environmental groups, pro-choice feminists, and trial lawyers to channel millions into Democratic coffers).

${ }^{17}$ It is often not possible for opposing interests to take advantage of the same technique as their adversaries. Different groups find different types of fundraising techniques and political action are most effective. For example, trial lawyers use "bundling" very effectively; many trial lawyers have incomes allowing them to donate $\$ 1000$ 
ply put, government cannot keep up with the fluid world of political campaigning.

Furthermore, it has long been noted that one major difficulty in reforming campaign finance laws is that most changes will be perceived as benefiting either Republicans or Democrats. As both sides will fight tooth and nail to block reform perceived as detrimental to their political prospects, reform efforts are prone to gridlock. ${ }^{18}$ If we add to this the noted propensity of campaign finance regulation to be particularly prone to the law of unintended consequences, ${ }^{19}$ we have a recipe for a system that creates more problems than it solves.

The alternative, we might note, is hardly more inviting-if gridlock does not set in, we might see constant tinkering with the law in an effort to gain partisan advantage. In short, campaign finance is an area in which we cannot afford to have the law in constant flux, due to the propensity of temporal majorities to aim for partisan advantage. Nor can we afford a static, heavily regulated system, due to its distortive effects on political life. Campaign finance, we must glumly come to realize, is a theatre in which the law is particularly illequipped to act.

\section{Opportunity}

A third problem is to design a system that does not discourage meaningful candidates from running. In this regard, the alleged shortcomings of an unregulated private system are well documented. ${ }^{20}$ Potential candidates can be prevented from running for office by their inability to raise the necessary funds, or discouraged from running by the difficulty of raising funds. Of course, this is more true in a regulated private system than in an unregulated one. A system that

to a campaign. This technique will be less effective for a group such as National Right to Life, whose members have lower incomes.

${ }^{18}$ See, e.g., Daniel Hays Lowenstein, On Campaign Finance Reform: The Root of All Evil Is Deeply Rooted, 18 HOFSTRA L. REV. 301, 335-36 (1989) (noting that a reform proposal by either party would probably work to the benefit of that party).

${ }^{19}$ See Samuel Issacharoff \& Pamela S. Karlan, The Hydraulics of Campaign Finance Reform, 77 TEX. L. REV. 1705, 1705 (1999) ("Electoral reform is a graveyard of wellintentioned plans gone awry."); Lowenstein, supra note 18, at 302-03 (discussing potential negative effects of campaign finance reform); Cass R. Sunstein, Political Equality and Unintended Consequences, 94 ColuM. L. REv. 1390, 1400-11 (1994) (arguing that various "reform" schemes wind up entrenching incumbents, producing more PACs, burdening PACs that represent labor or minority groups, and increasing soft money or secret gifts).

20 Seenerally Raskin \& Bonifaz, supra note 1 (arguing that financial resources are a decisive factor in elections). 
limits the size of private contributions makes it harder for all candidates to raise funds and almost always works against political outsiders and newcomers by making it harder for them to raise money relative to incumbents and well-known figures. ${ }^{21}$

There is little reason to believe that there are a large number of viable candidates for office who cannot raise the necessary funds in a deregulated system, as opposed to one that limits private contributions and spending. Most people who would have any chance of running a serious campaign for office can attract the necessary funds; and the freedom to raise and spend money increases the pool of viable candidates.

Perhaps this can best be shown through a simple thought experiment. Imagine that all campaign expenditures were banned. Who would surface as viable candidates for Congress? I strongly suspect it would be a small coterie of local celebrities (such as athletes, television personalities, and car dealers whose names are well-known from their business ads); current officeholders; a handful of successful business persons, lawyers, and physicians who have been extremely active in their professions or the community; and perhaps a few other well-known community leaders, such as the head of the local police or teachers' union, some community activists, or pastors of large churches. Overall, it is a group not too different from that which runs now, except probably a bit smaller in number and a bit less diverse. In an unregulated system of private finance, virtually all of these people could raise the money needed to run a serious campaign-in some cases from a large number of small contributions, in others from a small number of large contributions. ${ }^{22}$ The important thing is that some people not in this group can also raise the funds to become viable candidates.

As it is, candidates work frantically and spend their money in desperate attempts just to get the typical voter to know their names. ${ }^{23}$

${ }^{21}$ See Smith, supra note 3, at 1072-73 (arguing that limits on contributions require candidates to raise cash from a large number of small contributors, a process that is easier for those with name recognition).

${ }^{22}$ The current, heavily regulated system, however, works against many of these potential challengers, especially those who begin with low name recognition. See id at 1072 (arguing that officeholders have the advantages of established campaign organizations, past contributors to target, and the ability to raise funds on an ongoing basis from political action committees).

${ }^{23}$ At the height of the campaign season, a majority of persons of voting age cannot name either major party congressional candidate in their district. See Ilya Somin, Voter Ignorance and the Democratic Ideal, 12 CRITICAL REVIEW 413, 417 (1998). 
One cannot win without name recognition. Spending money allows a candidate without that initial name recognition to have a fighting chance. ${ }^{24}$ What makes us think that the ability of some candidates to spend money to gain name recognition somehow decreases the pool of viable candidates? Does Steve Forbes decrease the pool of viable Republican presidential nominees? Of course not. If anything, in both 1996 and 2000 his presence as a candidate seems to have increased interest in alternatives to the front runners, Bob Dole in 1996 and George W. Bush in 2000.

Nevertheless, a government finance system could potentially increase the pool of candidates beyond that of a deregulated private system by assuring that adequate financing is available to more candidates. But it could decrease that pool of candidates as well, if the incentives created to encourage acceptance of public financing make it extremely unlikely that a privately financed candidate can win, while at the same time setting the bar for government financing higher than most candidates can reach.

The problem here is in deciding who ought to receive government funds. Most observers seem to reject the notion that funds should be available to every potential candidate, seeing such a loose standard as a giveaway of public money. Funds need to be available on a broad enough basis to encourage "legitimate" candidates, but should not be so broadly available that the very availability of tax dollars for campaigning promotes frivolous candidacies. For this reason, most proposals for government financing require candidates to show a measure of "popular support."

The current presidential financing system, for example, provides "matching" funds to a candidate seeking his party's nomination who raises at least $\$ 5000$ in each of twenty states in amounts of $\$ 250$ or less. ${ }^{25}$ Contributions are then matched, up to $\$ 250$ per contribution, from the federal till. In the general election, party nominees receive public funds to run their campaigns in an amount determined by their showing in the last election. ${ }^{26}$

${ }^{24}$ This has been shown in numerous studies that emphasize the need for political challengers to spend enough to cross a viability threshold. Once across that threshold, they have a legitimate chance of winning; below that threshold, defeat is all but certain. See Bradley A. Smith, A Most Uncommon Cause: Some Thoughts on Campaign Finance Reform and a Response to Professor Paul, 30 CONN. L. REV. 831, 853 n.94 and sources cited therein (1998) (discussing the impact of campaign spending on votes).

${ }^{25}$ See 26 U.S.C. $\$ \$ 9033($ b), 9037 (1994).

${ }^{26}$ See 26 U.S.C. $\$ 9004$ (1994). The system is structured to make certain that the Republicans and Democrats will have the same amount of money in the general elec- 
This system appears to be both overinclusive and underinclusive in terms of financing candidates. It is overinclusive in that, under the system, a number of fringe candidates have qualified for federal matching funds, most notably convicted felon Lyndon LaRouche; John Hagelin of the Natural Law Party, which advocates greater use of transcendental meditation as the key government policy; and Lenora Fulani of the New Alliance Party, a socialist party which has been accused of engaging in cult-type brainwashing. ${ }^{27}$ It is also overinclusive in that a party may be eligible for general election funds based on past performance, even though it is unlikely to contest a future election. It is under-inclusive because any new major third-party nominee would not be eligible for funds prior to the general election. ${ }^{28}$

Other plans use other devices to cut the potential number of candidates who might make a claim on the government purse. For example, so-called "Clean Money Campaign Reform" bills being promoted by the lobbying group Public Campaign at the state level require candidates to garner a substantial number of $\$ 5$ contributions in order to qualify for government funds. As introduced in the U.S. Senate, ${ }^{29}$ a "Clean Money" bill requires the larger of either one thousand $\$ 5$ contributions or a number of $\$ 5$ contributions equal to one quarter of one percent of a state's voting age population. ${ }^{30}$ I have no way of knowing whether or not such a figure is too high or too low, and the truth is that the promoters of these bills do not either. ${ }^{31}$ The

tion and more than any other party's nominee.

27 See Jacqueline Salit, Breaking Bread with the Devils of Politics, NEwSDAY, Oct. 3, 1999, at B4 (discussing fringe candidates in the Reform Party).

${ }^{28}$ Such a candidate can receive funds after the election if he tops five percent of the vote. See 26 U.S.C. $\$ 9004$ (a) (1994). However, this is of little use to the candidate during the critical campaign before the election. Candidate John Anderson discovered this in 1980, when he was unable to borrow campaign funds before the election based on the anticipated receipt of federal funds after the election. Thus, Anderson's campaign floundered for lack of funds when needed-before the election. See Elizabeth Rada et al., Access to the Ballot, 13 URB. LAw. 793, 808 (1981) (discussing the constitutional implications of the discriminatory impact of existing law on Anderson and other independent candidates).

${ }^{29}$ Clean Money, Clean Elections Act, S. 982, 106th Cong. \$ 502 (1999).

${ }^{30}$ The Maine Civil Liberties Union has challenged a similar clause in Maine state legislation. The ACLU argues that this functions as an unconstitutional barrier to running for office, citing Bullock v. Carter, 405 U.S. 134 (1972), which limited filing fees for candidates. See Daggett v. Webster, 34 F. Supp. 2d 73, 74 (D. Me. 1999), vacated on other grounds, 172 F.3d 104 (1st Cir. 1999) (challenging Maine election law on First and Fourteenth Amendment grounds).

"One organization has described the proper figure as follows:

It must be high enough to screen out frivolous candidates who are unable to demonstrate a threshold level of support. At the same time, it must be low enough so as not to present a barrier to serious challengers. ... It should also 
sponsors recognize that this threshold is likely to be manipulated by incumbents seeking to protect their seats. ${ }^{32}$

In any case, the "Clean Money" plans are also both under- and overinclusive. They are underinclusive in that they will exclude late starting candidates who might otherwise gain substantial support but who do not have time to gather the necessary small contributions, and they will exclude serious candidates who have available substantial funds with which to campaign and raise name recognition, but who, prior to using those funds to campaign, lack the necessary organization, public support, and name recognition to gather lots of small contributions. ${ }^{33}$

They are overinclusive in that candidates who are not viable candidates will still qualify. As the lobbyists for these "Clean Money" bills admit, getting signatures on a petition is not truly representative of any level of popular support. ${ }^{34}$ Getting $\$ 5$ contributions is more difficult, and the theory is that few people will usually give money to a cause with which they are not in agreement. However, I will speak simply from personal experience: in my neighborhood a variety of political groups, including Greenpeace and various Public Interest Research Groups, regularly send young student volunteers or low-paid workers through the neighborhood to collect $\$ 5$ contributions for various causes. These volunteers appear at the door, describe a horrible problem facing the neighborhood, city, or state, and ask for a small contribution. I assume by their regular appearances that they

be noted that the required number will need to be reviewed and, probably, revised once the new law has been in effect.

Public Campaign, Clean Money Campaign Reform Annotated Model Legislation, comment to \$ 103(A)(2) (visited Oct. 29, 1999) <http://www.publicampaign.org/model_bill/ bill1.html\#103>.

${ }^{32}$ See id. (" $[1] \mathrm{t}$ will be easier to revise the numbers upwards than downwards (incumbents being unlikely to encourage more challengers)....").

${ }^{33}$ This illustrates a typical "reform" trap of mistaking the purpose of campaigns with the purpose of voting. The "Clean Money" acts are based on the premise that spending should reflect a pre-existing level of public support. In fact, it usually will, but there is no particular reason why it should: the purpose of spending money is to gain public support, not merely to reflect pre-existing popularity.

See Public Campaign, supra note 31, at comment to $\$ 103$ ('It's common knowledge that many people will sign anything but that very few people will contribute even a couple of dollars to a person or project they aren't in favor of."); see also PHIIIP L. DUBOIS \& FLOYD F. FEENEY, IMPROVING THE CAIIFORNIA INITIATTVE PROCESS: OPTIONS FOR CHANGE 84 (1992) (“[S]ignatures ... are simply not meaningful gauges of public discontent or even interest."); Daniel H. Lowenstein \& Robert M. Stern, The First Amendment and Paid Initiative Petition Circulators: A Dissenting View and a Proposal, 17 HASTINGS CONST. L.Q. 175, 199-200 (1989) (arguing that factors other than public support determine the success of a petition). 
find this to be a successful way to raise money. I doubt that most of the donors have any real idea about the issues involved, and my conversations with neighbors who have contributed confirm this. I doubt, therefore, that any real depth of public support will be found in collecting $\$ 5$ contributions through simplistic, one-sided presentations of issues to voters who otherwise know little or nothing about the candidate.

Government-financed campaigns might therefore be better or worse than a deregulated private system in promoting worthwhile candidates. It will depend largely on where the threshold is set for qualifying for funds. Given the uncertainties involved, the tendency for incumbents to protect themselves, and the fact that even a rule that at one point works well may periodically need revamping, which may come slowly or not at all due to the lack of flexibility in the system, I am skeptical that there is much to be gained from tax funding.

\section{Competitiveness}

Very similar problems arise when it comes to fostering competitive races. Professor Briffault argues that "[p]ublic funding would make the electoral process more competitive," but the comparison he makes is between a tax-funded system with adequate campaign funds, and a heavily regulated private system. ${ }^{35}$ In fact, since the era of heavy federal campaign finance regulation began in 1974, incumbent reelection rates have continued to rise and the number of competitive, or marginal, districts to decrease. ${ }^{36}$ Of course it is not clear that this trend is not a mere statistical blip, or perhaps caused by political background factors. ${ }^{37}$ It is certainly not true that this trend as a whole can be laid at the feet of campaign finance regulation. There are, however, reasons why limits on contributions and spending within a

${ }^{35}$ Briffault, supra note 2, at text following note 78.

${ }^{56}$ See Gary C. Jacobson, THE Electoral Origins of Divided Government: COMPETITION IN U.S. HOUSE ELECTIONS, 1946-1988 at 26-29 (1990) (reporting that the percentage of marginal incumbents-those winning with less than $60 \%$ of the twoparty vote-declined dramatically from 1974 to 1988); DANIEL HAYS LOWENSTEIN, ELECTION LAW: CASES \& MATERIALS 65458 (1995) (reporting that in terms of both vote percentage and re-election rates, incumbents in House elections have maintained an overwhelming electoral advantage since the mid-1960s); DANIEL H. LOWENSTEIN \& RICHARD L HASEN, ELECTION LAW: SUPPLEMENT 1999-2000, at 84 (1999) (demonstrating that the same trend has continued in the last two House election cycles).

${ }^{37}$ See, e.g., JACOBSON, supra note 36, at 133 ("Electoral swings have been modest in recent elections because national conditions and issues have not been conducive to change."). 
privately financed contribution system distort political campaigns in favor of incumbents. ${ }^{38}$ For instance, prior to the passage of FECA, challengers in U.S. House races tended to raise about $\$ 0.67$ for every dollar raised by incumbents. After FECA, that number dropped to about $\$ 0.25$ by a challenger for every dollar raised by incumbents before rebounding somewhat to its recent level of $\$ 0.42$ per incumbentraised dollar. ${ }^{39}$

Whether or not government financing will improve the situation of challengers relative to a deregulated private system is open for debate. In those two states which have meaningful experience with tax financing for their state legislatures, studies of government financing systems have yielded mixed results. A 1995 study of Minnesota's system by Patrick Donnay and Graham Ramsden concluded that Minnesota's system "promises more competitive campaigns, but does not go far toward creating them." ${ }^{\text {"40 }}$ A study of Wisconsin's system by Kenneth Mayer and John Wood seemed to yield a similar result. They concluded that "public financing has had no effect at all on the level of electoral competition," and "public financing of congressional elections, by itself, will not eliminate the problem of uncompetitive elections. ${ }^{411}$ In a later study, however, Professor Mayer argues that "a welldesigned and adequately funded public finance program can dramatically increase competition levels. ${ }^{42}$

So, will government financing foster competitive elections? Again, it depends on the type of financing system that might be adopted. For example, to the extent that government financing with a spending cap equalizes expenditures, it might help challengers, who are usually outspent even in a deregulated system. Public financing, however, also

${ }^{3 s}$ See Smith, supra note 3, at 1072-75 (arguing that contribution limits benefit incumbents, who have fundraising advantages and generally need to spend less because they benefit from office-related press coverage and name recognition).

${ }^{39}$ See NORMAN J. ORNSTEN ET AL., VITAL STATISTICS ON CONGRESS, 1997-1998, at 87 (1998) (listing challenger/incumbent spending ratios from 1976 to 1996 for the U.S. House of Representatives).

${ }^{10}$ Patrick D. Donnay \& Graham P. Ramsden, Public Financing of Legislative Elections: Lessons from Minnesota, 20 LEGIS. STUD. Q. 351, 362 (1995). The authors attribute this failure to the program's design which, not surprisingly, gives more benefits to incumbents than to challengers. See id.

${ }^{11}$ Kenneth R. Mayer \& John M. Wood, The Impact of Public Financing on Electoral Competitiveness: Evidence from Wisconsin, 1964-1990, 20 LEGIS. STUD. Q. 69, 70, 86 (1995).

12 KenNeth R. Mayer, PUblic Financing and Electoral Competition in MINNESOTA AND WISCONSIN 17 (1998). Mayer argues that the true measure of competitiveness is less how many incumbents actually lose than how many are involved in close races. See id. at 8 . 
prevents challengers from ever spending more than incumbents. Given the tremendous value of incumbency, many believe that challengers are only on equal footing with incumbents when they can spend more. ${ }^{43}$ Challengers in a position to spend more than an incumbent are usually the strongest challengers. Thus, a flat spending cap may harm those challengers most likely to actually defeat an incumbent.

Complicating the question further, strong evidence suggests that the key variable is not really who outspends whom, but whether challengers spend "enough" to make their names and positions known to the public. ${ }^{44}$ Thus, a government financing system with an expenditure cap that sets the limits high enough may make races more competitive, while a system that sets the spending level too low may make races less competitive. The presence of adequate funding is a key element to Mayer's 1998 findings that public financing can "dramatically increase" competition. ${ }^{45}$

But can we expect government to set funding at adequate levels? As Professor Mayer notes, Wisconsin has failed to do so. ${ }^{46}$ One reason that it is difficult to assure that government funding is both enacted or maintained at adequate levels is that it is easily criticized as "welfare for politicians," and as an unnecessary state expense in any period of budget cutbacks or austerity. ${ }^{47}$ There is, quite simply, "no hint of a po-

13 See Raskin \& Bonifaz, supra note 1, at 289 (finding that the financial advantage of incumbency has two aspects: public self-subsidies Congress bestows on its members, and private money seeking legislative influence).

11 See, e.g., AlAN I. ABRaMowitz \& JeFFrey A. SEgal, SENATE Elections 139 (1992) ("[D]ollar for dollar, spending by challengers and open seat candidates should produce a greater electoral return than spending by incumbents."); GARY C. JACOBSON, THE POLITICS OF CONGRESSIONAL ELECTIONS 130-32 (3d ed. 1992) (discussing the correlation between a challenger's level of campaign spending and the probability that a voter will report having contact or familiarity with him or her); Alan I. Abramowitz, Explaining Senate Election Outcomes, 82 AM. POL. SCI. REV. 385, 397 (1988)(concluding that " $[t]$ he challenger's campaign expenditures are the single most important variable affecting an incumbent senator's chances of being reelected"); Jeffrey Milyo, The Electrical [sic] Effects of Campaign Spending in House Elections (visited Oct. 15, 1999) <http: $/ /$ www.igs.berkeley.edu:8880/CRF/RS/milyo.html (suggesting that incumbents that marginally outspend their challengers do not benefit from their additional expenditures)).

${ }^{45}$ See MAYER, supra note 42, at $3-4$ (describing Minnesota's system as successful, in part because it has higher spending limits and allows for different levels of expenditures in different types of races-including a $10 \%$ increase in spending for first time candidates).

${ }^{45}$ See id. at 2, 17-19 (noting that Wisconsin's spending limits have remained the same since 1986).

${ }^{47}$ See id. at 17 (challenging the notion that public funding has a negative effect on 
litical will to dramatically expand the levels of [public] financing. ${ }^{48} \mathrm{~A}$ partial solution to the problem of the public's miserly attitude toward government financing of campaigns can be found in a creative proposal by Professor Daniel Hays Lowenstein. ${ }^{49}$ Lowenstein proposes that government funds go not to candidates, but to political parties, which could then distribute the funds. The advantage to this system is that party leaders should tend to spend their funds on competitive races, but will not provide substantial funds for races that appear to be lopsided. This should support competitive races while keeping overall costs lower than if equal funding were given to each candidate. Not only would this be a more efficient use of campaign funds, but it could keep "safe" incumbents from further entrenching themselves through large spending in a non-competitive race-thus making a competitive race more likely in the future. This is, at best, only a partial solution; there will still be pressure to lower the amounts provided to uncompetitive levels. Indeed, since many Americans distrust political parties, Lowenstein's proposal, if enacted, may actually increase the antipathy to providing adequate funds. ${ }^{50}$

A second reason why spending caps will likely be set too low is simply that incumbents, who want to be reelected, will set the levels of the caps. For example, when Congress debated spending caps in 1997, the bills establishing those caps set the spending limit at a level at which challengers could not be competitive." Every challenger spending less than the proposed limit in Senate campaigns had lost in each of the 1994 and 1996 elections, whereas every incumbent spending less than the limit had won. Similarly, only $3 \%$ of challengers spending less than the proposed limit for House races had won in 1996, whereas $40 \%$ of challengers spending more than that limit had won. ${ }^{52}$ It is not necessary to attribute pernicious intentions to legislators to realize the danger that limits will constantly be set too low. Incumbents, who already have substantial name recognition and know

the level of electoral competition).

${ }^{48}$ Issacharoff \& Karlan, supra note 19, at 1735.

${ }^{49}$ Lowenstein, supra note 18, at 351 (outlining a reform package for general elections using a "party allocation system").

${ }^{50}$ See Alan Greenblatt, Politics and Marketing Merge in Parties' Bid for Relevance, 55 CONG. Q. WKIY. REP. 1967, 1969 (1997) (citing 1997 statistics showing that $48 \%$ of the electorate, a plurality, identified themselves with neither political party).

${ }^{51}$ See S. 25, 105th Cong. $\$ 503$ (d) (1) (1997) (setting a spending limit of $\$ 5.5$ million for Senate races); H.R. 493, 105th Cong. $\$ 502$ (b)(1)(101) (1997) (setting a spending limit of $\$ 600,000$ for House races).

${ }^{52}$ See Bradley A. Smith, Why Campaign Finance Reform Never Works, WAII ST. J., Mar. 19, 1997, at A19 (citing statistics compiled from FEC reports). 
how much they need to run an effective campaign, may simply have forgotten how much challengers need to spend to run an effective campaign.

Worse, even if the original grant seems adequate, it may not remain so. For example, in the federal system, it appears that the amounts allotted to the major parties for the general election of the president, even though adjusted for inflation, are no longer adequate. $^{53}$ This deficiency has prompted increased spending on "issue advocacy" and increased amounts of "soft money" contributions. ${ }^{54}$ In Wisconsin, spending limits have not been raised since 1986, becoming, in the process, woefully inadequate. ${ }^{55}$ Thus, we see that the lack of flexibility within a government financing campaign, coupled with political pressures to reduce spending, makes it difficult to keep government grants and limits adequate, even if they were adequate when first enacted.

Of course, the argument that the spending cap may be set too low is easily rebutted by proposing a program-such as Minnesota's, perhaps-in which the cap is set at an appropriate level and indexed for inflation. But it is legitimate to question whether the incentives and dynamics of the issue make it more likely than not that a government financing system will come to favor incumbents. Professor Briffault is correct in suggesting that a tax finance system can assure that all candidates, especially challengers, have the critical mass of funds necessary to make them competitive. That same system, however, can also be used to lock in incumbents and deter serious challengers. Considering the limited experience at the state and federal level and what we know about political behavior, a government financing system could increase competitiveness, but probably will not.

${ }^{53}$ See Stephen Ansolabehere \& James M. Snyder Jr., Money and Institutional Power, 77 TEx. L. REV. 1673, 1704 (1999) (finding that increases in the presidential campaign limit have failed to match the similar increases for congressional races because the limits are indexed to different economic indicators).

${ }^{54}$ See id. at 1702-04. "Issue ads" are advertisements that may be intended to influence voters by discussing candidates' views on issues, but which stop short of urging people to vote one way or another. "Soft money" consists of unregulated contributions made to political parties, rather than candidates, for purposes of party building, which may include "issue advertising." See Bradley A. Smith, Soft Money, Hard Realities: The Constitutional Prohibition on a Soft Money Ban, 24 J. LEGIS. 179, 182-84 (1998) (examining the links between soft money and issue advocacy).

${ }^{55}$ See Mayer, supra note 42, at 2 (comparing Wisconsin's campaign spending limits to those of Minnesota where higher limits and an indexing system have more effectively fostered competition). 


\section{E. Communication}

While addressing the difficulty of providing for funds adequate to foster competition, we have already considered the electoral advantages of incumbency. One reason that incumbents do well when spending caps are set too low is that voters are deprived of both information about challengers and information that challengers would provide about incumbents. Because voters start with more information on incumbents, but rarely with any concerted effort to find potential flaws with the incumbent, low spending favors incumbents. Also, because challengers are less well-known, and usually receive less free coverage than incumbents (by virtue of not holding office or engaging in the public acts and discussion that go with holding office), low spending tends to penalize challengers. Again, it is certainly possible to devise a government system that provides for adequate funds, but there is little reason to think that such a result is likely or, even if temporarily achieved, that funding levels will remain adequate. Without campaign spending, voters' information is limited to what they can get through the free media.

A deregulated private system may not always provide adequate funds to challengers, but given that the general thrust of political reform efforts is to reduce the amount spent on political campaigns, I am not optimistic that government financing will increase voter education levels.

Unlike some supporters of government financing, Professor Briffault resists the temptation to demonize private financing, providing a generally balanced account. But the model of private financing against which he compares government financing is the current, highly regulated model, rather than the alternative of a deregulated system. Even if he avoids demonizing private financing (heavily regulated or not), his vision of a government-financed system is quite idealized.

Overall, there are no guarantees that a tax-financed system will perform better than a deregulated private system judged on any of these criteria of administrability, flexibility, opportunity, competitiveness, or communication. Tax financing does offer potential improvements in some areas, but what we know about politics and government regulation suggests that such benefits are unlikely to be realized. In fact, negative consequences are perhaps the more likely result. 


\section{CLASHING VISIONS: EQUALITY AND CORRUPTION}

I have set aside, until now, the two prime arguments usually offered up in support of tax financing: that it is necessary to assure equality and to prevent corruption. The resolution we have been asked to discuss assumes two extremely important facts. First, it presumes that there is some problem, described as "the political influence of special interests," which must be addressed. Second, it presumes that taxpayer financing and spending limits will solve this problem. Given that there are no particular advantages to government financing outside of the alleged benefits for equality and control of corruption, we should closely examine each of these assumptions. The first I examine here, the second in Part IV.

\section{A. The Question of Influence}

When we say that we want to control the influence of "special interests," we need first to remember that one person's "special interest" is another's "vital national interest." Rarely does a labor union leader stride boldly to the microphone and announce that his members favor a prevailing wage law because they want as much as possible for themselves, taxpayers take the hindmost. Rarely does a corporate executive argue that import duties are bad for the country, but he does not care so long as his company benefits. More subtly, is the Sierra Club a "citizens' lobby" or a "special interest"? It may depend on whether you want to hike in the wilderness and preserve species, or drive on the freeway and preserve jobs in the timber industry. How about the National Rifle Association? The United Auto Workers? The Grange? Are they "special interests" or "citizens' groups"? Until we can all agree on the answers to these questions, I am not sure that the idea of combating "special interests" gets us very far. I personally oppose tariffs and import quotas on foreign textiles. Try telling the employee about to lose her job due to cheap textile imports that she is a "special interest." This problem alone should make us skeptical of trying to reign in "special interests."

Assuming that we could agree on the answers to these questions, we would still have the problem of defining what kind of influence we want to block. The object of participating in politics is to have "influence" in the political system. If it were not, why would anyone participate ${ }^{56}$ Thus, the editors' proposition seems to presume that certain

\footnotetext{
${ }^{56}$ See Lillian R. BeVier, Campaign Finance Reform: Specious Arguments, Intractable Di-
} 
types of influence are in some way illegitimate and need to be controlled or eliminated. Further, it presumes that such influence is linked to political contributions. Political contributions can arguably provide influence in two different ways. The first is that they alter the way in which legislators behave while in office. The second is that they affect the way that voters vote. The first is usually the subject of the anti-corruption argument, and the second, the "equality" argument. I will take up the equality issue first.

\section{B. Equality}

In Buckley, the Supreme Court held that the pursuit of equality is an insufficiently compelling government interest to justify infringements on the First Amendment. ${ }^{57}$ This holding, however, hardly takes the issue off the table. Equality can certainly be a legitimate political objective, and its pursuit in a constitutional manner-such as through a truly voluntary system of government financing-may be a sound policy objective. However, the notion that removing one source of political influence from politics (money) while leaving others (such as writing and organizational ability) intact will add to equality is based on a combination of dubious empirical assertions, a romantic notion of politics, and a core philosophical definition of equality that is certainly debatable.

The first empirical assertion is the unproven and rather unlikely notion that other sources of political influence-such as good looks, speaking ability, time, or more importantly, celebrity, writing ability, free media access, campaign organizational skills, and the like-are more evenly spread across the populace and the political spectrum than is wealth. ${ }^{58}$ This view is unlikely because it seems rather clear that

lemmas, 94 COLUM. L. REV. 1258, 1267 (1994) (questioning the logic behind campaign finance reform in light of its goal for achieving political equality).

${ }^{57}$ See Buckley v. Valeo, 424 U.S. 1, $48-49$ (1976) (invalidating certain provisions of the Federal Election Campaign Act of 1971, as amended in 1974, as violative of the First Amendment).

${ }_{58}$ See Richard L. Hasen, Campaign Finance Laws and the Rupert Murdoch Problem, 77 TEX. L. REV. 1627, 1646 n.101 (1999) (arguing that those with personal attributes, such as celebrity, capable of affecting the electoral process are evenly spread across the political spectrum). Professor Hasen casually asserts the proposition that "celebrity views are likely to be randomly distributed on the political spectrum." Id. at 1646 n.101. I find this a most curious assertion for several reasons. First, Hasen never makes an effort to prove it or even to show that it flows logically from some proposition. Since it is not at all obvious to me, or to most people with whom I communicate regularly, that this is true, I have to discount this assertion. Second, I do not understand why Professor Hasen would be convinced that "corporations" (meaning the peo- 
in virtually every major political debate or campaign, both sides (or all sides with any serious measure of popular support) are reasonably well-financed. Moreover, because wealth is a reward generally available to those who gain success in athletics, in Hollywood, through campaign consulting, and most any other profession, persons with other sources of influence tend to be subsets of those with wealth. It is to be expected that the larger group of "people with money" will have a broader spectrum of political views than any given subset. If this is true, barring monetary contributions but leaving other sources of influence intact will lead to fewer, not more, views being represented. ${ }^{59}$

It is also argued that money must be excluded because unlimited spending allows some voices to "drown out" others. This is empirically not true. There are now so many media outlets-including magazines, twenty-four hour news channels (including two exclusively devoted to government), a booming talk-radio market, the internet, and more, available for free or virtually so (visit the local library) -that a prospective voter can get just about any perspective he or she might conceivably want $^{60}$ We must not mistake the listener's disinterest for the communicator's inability to speak.

Of course, most of these low cost information sources must be sought out by the voter. A well-financed candidate can simply blast passive viewers with television ads, but this does not "drown out the opponent." At worst, it simply means that many voters-those who get all their information from television ads-hear only one side (assuming only one side has sufficient funds to run ads-a dubious assumption in many, if not most, serious campaigns). The argument for

ple who run and own them) share common political views, but people in other walks of life who have greater than average political influence, such as Hollywood or academia, would not have certain widely shared views within their professional circles. See id. at 1646. Finally, if Professor Hasen really does perceive such a difference, is his game not up? For it would then appear that his goal is to disadvantage certain political viewpoints (those held by corporate owners and managers) rather than to promote any particular type of "equality." If one is truly interested in "equality," I am puzzled as to why celebrities, academics, reporters, campaign consultants, and others with "undue" political influence should be allowed to have such influence, regardless of the distribution of their views along the political spectrum.

${ }^{59}$ This argument might fail if these subsets of wealthy people tend to disproportionately share a common political philosophy with all other people of wealth. In this case, banning money will make no difference.

${ }^{60}$ See Issacharoff \& Karlan, supra note 19, at 1726 (noting the ease with which consumers of political news can obtain information about competing viewpoints). But $c f$. Daniel R. Ortiz, The Democratic Paradox of Campaign Finance Reform, 50 STAN. L. REV. $893,902-03$ (1998) (discussing how inequality of opportunity to reach a voter does not rest primarily on a candidate's resources, but on the voter's level of interest). 
campaign spending limits seems to assume that we would be better off if those voters heard from neither side before heading off to vote. This is a puzzling perspective, and one which would almost certainly leave politics to a mix of car salesmen, television anchormen, sports stars, state and local officeholders, and those few others who might already possess local name recognition-a more narrow group than the current crop of candidates.

The solution to the problem of limited voter information, again, is to increase spending by candidates so that all are heard. A government finance system with adequate spending levels might do this; one with inadequate spending levels will not, and will probably be worse than an unregulated private system. The problem, again, is what kind of financing system the political system is actually likely to yield.

The idea that money is in some way different from other sources of political influence also draws on a romantic idea of politics. All of us do not have equal monetary resources, but in theory, at least, all of us can volunteer to walk a precinct, man a phone bank, stuff envelopes, or write a letter to the editor. ${ }^{61}$ Twenty-four hours spent working on a campaign by most Americans, however, are certainly not as valuable as are twenty-four hours of James Carville's time spent working on the same campaign. To put it another way, what the "average" citizen can do, non-monetarily, for a campaign-stuff envelopes, distribute a few brochures door to door, and the like-is the equivalent of a ten to twenty dollar campaign donation. But there are some citizens-campaign managers such as Carville; activist celebrities such as Arnold Schwarzenegger, Lauren Bacall, or Barbara Streisand; writers such as George Will or Elaine Goodman-whose political influence far, far exceeds those of most citizens. Campaign endorsements or participation by such individuals are the equivalent of $\$ 5,000, \$ 50,000$ and $\$ 250,000$ donations. ${ }^{62}$ As with money contributions, most citizens are capable only of small contributions of non-monetary resources, while only a select few "large donors" can really wield significant influ-

${ }^{61}$ Of course, the reality is that we are not all equal there, either-even those of us with strongly held political views. My 91 -year-old grandmother can no longer do any of those things, but when it comes to politics, "don't get her started ...."

${ }^{62}$ Surely, all the ink spilt by the many talented and well-positioned advocates amounts to a multi-million dollar sub rosa subsidy to those political candidates running on a reform platform. My participation in this debate rests on the conviction that each citizen should be able to use every asset, skill, or talent he or she possesses to promote his or her views. Does not the reformers' agenda suggest that every citizen's voice should be reduced to the level of the least able participant? And if so, how do they justify the use of their unusual privilege and talent to be heard? 
ence. Professor Briffault tells us that just 235,000 people contributed one-third of the private money for federal campaigns in $1996 .^{63}$ Leaving aside the millions of donors who contributed the remaining bulk of the private funds, I am quite certain that 235,000 is a considerably larger group than the number of people who were offered op-ed space in daily newspapers; or the number of people who served as campaign managers in federal campaigns; or the number of people who filed amicus briefs in the Supreme Court; or the number of people who head advocacy groups arguing for campaign finance reform. Indeed, I am quite certain that these large donors make up a more numerous and more diverse group than all of the above combinedand yet comprise a group with less political influence than the above. Professor Briffault adds that these 235,000 are not typical of all Americans. ${ }^{64}$ Not to be overly flippant, but tell us something that we do not know about journalists, consumer "activists," or most any other class of people wielding political power. Tell us something, indeed, that we do not know about the elected representatives themselves. Let us focus not just on the "evil" attributes of these 235,000 (they are more likely to be "affluent, men, [and] whites" as well as "more conservative ... [and] more Republican"); ${ }^{65}$ let us also consider that compared to most other people with political influence, they are less likely to work for government, less likely to be college professors, more likely to have met a payroll, more likely to live outside of the federal capital, less likely to be Democrats, and in each of these and many other ways, they are more like "the general population." In short, though they are in many ways different from 'the general population,' in a great many other ways they are more like the general population than those whose influence would increase if these 235,000 were cut out of the process.

At this point, the debate over equality tends to shift to philosophical ground, with supporters and opponents of banning private contributions arguing for very different views of what constitutes "equality." Much has been written on the subject, ${ }^{66}$ and I doubt that we can add

${ }^{63}$ See Briffault, supra note 2, at text accompanying notes $40-41$.

See id. at text accompanying notes $41-42$.

${ }^{65} I d$ at text accompanying note 42.

${ }^{66}$ See, e.g., Charles Fried, The New First Amendment Jurisprudence: A Threat to Liberty, in THE BILI OF RIGHTS IN THE MODERN STATE 225, 228 (Geoffrey R. Stone et al. eds., 1992); Lillian R. BeVier, Money and Politics: A Perspective on the First Amendment and Campaign Finance Reform, 73 CAL. L. REV. 1045, 1047 (1985) (noting that defenders of lenient judicial scrutiny for campaign finance reform legislation argue that equalizing access to the political process is intrinsically related to the First Amendment); Edward 
much here beyond a brief summary of those competing views.

We might call those who would like to destroy monetary participation in politics the Platonists. Platonists believe that individuals blessed with certain types of talents are inherently entitled to greater political influence than their fellow citizens. The Platonist view holds that citizens with skills and attributes directly valuable to politicsspeaking, writing, political organizing, media access (as with celebrities), good looks, etc.-deserve their unequal political influence, and by right and breeding ought to serve as platonic "rulers" of the republic's body politic. ${ }^{67}$ Therefore, inequalities in these attributes should not concern us. Those who possess other skills-in medicine, business, computers, or manufacturing, for example ${ }^{68}$-may or may not deserve the wealth that their skills bring to them, but they definitely do not deserve political influence. ${ }^{69}$ Thus, expenditures of money by such individuals, or what we should recognize as efforts to convert their non-political skills into political influence, are illegitimate. And because wealth is not equally distributed across the populace, this type of influence is a great concern.

Against this view stand those whom we might dub the Stoics. The Stoic thinkers on campaign finance believe in strict equality before the law. In this view, all citizens should have an equal opportunity to use their talents-any talents-to influence political life. This means

B. Foley, Equal Dollars Per Voter: A Constitutional Principle of Campaign Finance, 94 CoLUM. L. REV. 1204, 1206 (1994) ("[E]ach eligible voter should receive the same amount of financial resources for ... participating in electoral politics."); Stephen E. Gottlieb, The Dilemma of Election Campaign Finance Reform, 18 HOFSTRA L. REV. 213, 220 (1989) (noting that the very definition of equality is a contested concept in this area); Richard L. Hasen, Clipping Coupons for Democracy: An Egalitarian/Public Choice Defense of Campaign Finance Vouchers, 84 CAL. L. REv. 1, 27 (1996) (arguing that a voucher plan would best serve egalitarian pluralism); Raskin \& Bonifaz, supra note 1, at 278-79 (positing that equal protection "provides the principal constitutional paradigm" for analyzing questions about the political process).

See Plato, The RePUblic of Plato chs. VIII-X (Francis MacDonald Cornford trans., 1961); $i d$. at 122 (" $[\mathrm{I}] \mathrm{f}$ a state is constituted on natural principles, the wisdom it possesses as a whole will be due to the knowledge residing in the smallest part, the one which takes the lead and governs the rest.").

6s These positions are the modern equivalent of the craftsmen, merchants, and laborers in Plato's Republic According to Plato, though necessary to an economically sound state, "on intellectual grounds they are hardly worth including in our society." Id. at 58.

${ }^{69}$ See E. Joshua Rosenkranz, Faully Assumptions in "Faulty Assumptions": A Response to Professor Smith's Critiques of Campaign Finance Reform, 30 CONN. L. REv. 867, 894 (1998) ("The power of persuasion, which involves skills 'such as writing and speaking goes to the heart of what the First Amendment is about. . .' [M]oney spent to broadcast an idea is completely unrelated to the value of the idea it propels or the influence of the message on the listener."). 
that citizens must be allowed to convert all of their abilities into political influence in the form of contributions. This is a broader, more plebian, more free-wheeling conception of democracy which allows more people to play the game. ${ }^{70}$ It denies that certain political views have inherent merit merely because the speaker possesses certain types of skills. Rather, it promotes equality before the law. ${ }^{71}$ Stoic thinkers are relatively unconcerned, then, when an individual or group of individuals gives or pays money to a candidate, a political party, an ad agency, or some other group to promote political views similar to those of the contributor. Stoics see this as enhancing equality by allowing all politically involved citizens to use their diverse assets to promote their political beliefs. The fact that monetary assets are unevenly distributed, as are the political skills of writing, speaking, managing campaigns and so forth, is of little concern to Stoics, who accept it as a fact of life. The Stoic view is inherently unattractive to academics, journalists, and "good government" lobbyists. These people tend to possess skills with direct political utility and also tend to believe that their political views are better informed than those of most citizens. Naturally then, they are drawn to the Platonist vision, which affirms their greater worthiness to participate in political discussion and grants them greater political power. ${ }^{72}$

The philosophical conflict between the Platonist and Stoic views of campaign finance is not one that can be resolved here, but there is another aspect to the discussion. On a practical level, there are those of us who doubt that most campaign finance regulation accomplishes what it is intended to accomplish. Thus, we have argued that even accepting the Platonist definition of equality favored by self-styled "reformers," regulation-including government financing-both has

${ }^{70}$ See Gottlieb, supra note 66 , at 284 ("[W] echo,' a wide-open system of campaign finance may prove appropriate."); Issacharoff \& Karlan, supra note 19, at 1732 ("[F] or some people, the most articulate statements of their political preferences they can make involve contributing money ...."); Smith, supra note 2, at 73-76 (concluding that money allows more voices to be heard, while limiting campaign contributions tends to silence voices).

${ }^{71}$ See RICHARD PIPES, PROPERTY AND FREEDOM 12 (1999) (explaining briefly the history and nature of Stoicism).

${ }_{72}$ Professors Issacharoff and Karlan have made the same observation:

Thus, it is hardly surprising that the scholarly argument for campaign reform would produce a world in which intellectuals would have more influence and the persons they have chosen not to be-businessmen or people who devote their working hours to earning a living in a fashion that does not involve having and disseminating deep political thoughts-will have less.

Issacharoff \& Karlan, supra note 19 , at 1731 . 
been and will continue to be a bad thing. ${ }^{73}$ Regulation, by its very nature, casts the heaviest burden on those who lack the resources to hire lawyers, accountants, and consultants to advise them on the law and their campaigns. It also favors incumbents and others who already know how to play the system and use it against their opponents. ${ }^{74} \mathrm{Re}-$ stricting influence through campaigning can increase the influence of those with a permanent presence at the seat of government; this group consists overwhelmingly of powerful industrial and union interests, not lobbyists for the disorganized and disempowered. ${ }^{75}$

Moreover, if I am right about the lack of flexibility in government finance systems and the tendency of incumbent lawmakers to skew systems to their advantage, these "undemocratic" consequences of campaign finance regulation may be all but unavoidable in a tax-financed system. At least in theory, a better system might be developed. I am skeptical, however, that proponents of government financing can design a plan that will do what they hope it will.

\section{Comuption}

The second interest allegedly furthered by tax financing of campaigns is the elimination of a second type of "special interest" influence-influence in the political process after the votes are counted. This is often referred to by regulatory advocates as "corruption. ${ }^{76}$ As

${ }^{73}$ See THOMAS GAIS, IMPROPER INFLUENCE 181 (1996) (arguing that past electoral reforms and regulations have led to representational deficiencies in the PAC system); BeVier, supra note 66, at 1076 (arguing that commentators favoring campaign finance reform discount the value of the contributors' First Amendment rights); Gottlieb, supra note 66, at 286-92 (pointing out the potential adverse impact of campaign finance reform proposals on First Amendment rights); Smith, supra note 3, at 1050 (arguing that campaign finance regulation conflicts with accepted notions of equality and is undemocratic); see also Joel M. Gora, Campaign Finance Reform: Still Searching Today for a Better Way, 6 J.L. \& POL'Y 137, 165 (1997) (noting that the constitutionality of many proposed reforms is suspect); Sanford Levinson, Regulating Campaign Activity, 83 MicH. L. REV. 939, 948-49 (1985) (book review) (arguing that campaign finance reform does not address the fact that other socially useful resources which can affect electoral results are also unequally distributed).

${ }^{74}$ See Smith, supra note 3, at 1083 (" [C]ampaign enforcement actions are disproportionately directed at challengers, who are less likely to have staff familiar with the intricacies of campaign finance regulation.").

${ }^{73}$ See GAIS, supra note 73, at 132 (noting that "the PAC system highlights certain policy domains and underrepresents others"); see also Edward A. Kangas, Sofl Money and Hard Bargains, N.Y. TIMES, Oct. 22, 1999, at A27 (arguing that "lobbyists and trade associations" would allow big business "to be heard" even if soft money were banned and supporting such a ban).

${ }_{76}$ See, e.g., Fred Wertheimer \& Susan Weiss Manes, Campaign Finance Reform: A Key 
always, we need to begin this debate by pointing out that by "corruption," reform advocates do not mean traditional bribery. Traditional bribery in terms of funds that line the lawmaker's pockets in exchange for specific official action is already outlawed. What regulatory advocates seem to mean by corruption is that lawmakers will vote in certain ways, once in office, in order to please contributors, rather than in some other, better manner." I find it rather implausible that this is really a major problem in American government.

For one thing, the assertion that lawmakers vote to please financial contributors is simply not supported by the bulk of systematic evidence. Serious studies of legislative behavior have overwhelmingly concluded that campaign contributions play little role in floor voting, ${ }^{78}$ and these conclusions are no longer seriously disputed by the would-be regulators. ${ }^{79}$ Instead, it is now argued that the corruption exists where it is harder to see-in committee activities, in "the speech not given," and in prioritizing. Of course, if "corruption" cannot be measured or seen, this assertion cannot be disproven, which is something of a handicap to labor under for those of us skeptical of this justification. On the other hand, this assertion is backed only by bits of anecdotal evidence, usually quotes from present and former legislators explaining their support for campaign finance regulation or explaining why they were unable to accomplish certain legislative objectives. $^{80}$ This evidence is not terribly persuasive. There is a human tendency to blame defeat on "unfair" factors such as "corruption," rather than to admit that our ideas were not strong enough, our allies not numerous enough, or our side not organized enough, to gain legislative victory. There are also anecdotal quotes running in the oppo-

to Restoring the Health of Our Democracy, 94 COLUM. L. REv. 1126, 1159 (1994) (describing the current system for financing congressional campaigns as "corrupting").

${ }^{n}$ See Thomas F. Burke, The Concept of Comuption in Campaign Finance Law, 14 CONST. COMMENTARY 127, 131 (1997) (outlining subtler forms of corruption under which lawmakers perform their duties with monetary considerations in mind).

${ }^{78}$ See id. at $139 \mathrm{n} .45$ and sources cited therein (indicating that "contributions do influence representatives, but less than many suppose"); see also Stephan G. Bronars \& John R. Lott, Jr., Do Campaign Donations Alter How a Politician Votes? Or, Do Donors Support Candidates Who Value the Same Things That They Do? 40 J.L. \& ECON. 317, 346 (1997) (concluding that empirical data fail to support the notion that campaign contributions buy politicians' votes).

${ }^{79}$ But see Rosenkranz, supra note 69 , at 877 (arguing that even though the presence of corruption is not supported by voting pattern studies, it still pays a major role in influencing representatives).

${ }^{80}$ See, e.g., Wertheimer \& Manes, supra note 76, at 1129 (quoting former Senator Paul Douglas, who feared that the influence of money and favors "may be so subtle as not to be detected by the official himself"). 
site direction. ${ }^{81}$ In addition, there is the inability of regulatory advocates to actually name corrupt legislators or episodes of such "corruption." The fact is, it is still shocking when episodes such as "Abscam" and the "Keating Five" come to light, precisely because such episodes are rare. Conventional wisdom aside, most people do not do it.

A bit of reflection tells us why it is unlikely that money "corrupts" the legislature to any great extent. For one thing, personal conviction, party agenda, and public opinion seem far more logical explanations for most legislative activity. ${ }^{82}$ Campaign money is of little value if it cannot be turned into an electoral victory, ${ }^{83}$ and it makes little sense to betray one's personal convictions, lose the support of one's party, and offend public opinion in order to obtain a contribution. Other factors that undoubtedly affect a legislator's actions might include anticipated newspaper endorsements or the slant of reporting, including deciding what qualifies as "news"; the opinions of staffers and personal friends and family; perceptions of whether or not a stand on an issue could be distorted by an opponent into an effective campaign attack; potential endorsements by interest groups; and (I suspect) a host of other factors. ${ }^{84}$

${ }^{81}$ See, e.g., Hearings on Campaign Contribution Limits Before the Senate Comm. on Rules and Administration, 106th Cong. (Mar. 24, 1999), available in 1999 WL 8086675, at *6 [hereinafter Hearings on Campaign Contribution Limits] (statement of former Senator Dan Coates) ("Never, not once... have I witnessed or been informed of the exchange of dollars for political favors. Not by me or my supporters, not for any amount of money, and not by anyone I have known or served with."). Senator Coates spent 18 years in Congress, in addition to four more as a congressional aide. See id. at *1.

${ }^{82}$ See STEPHANIE MOUSSALII, CAMPAIGN FINANCE REFORM: THE CASE FOR DEREGULATION 6 (1990) (reporting that studies show that ideology, party, politics, and constituency factors have a stronger influence than campaign contributions); FrANK SORAUF, MONEY IN AMERICAN ELECTIONS 316 (1988) ("[T] he evidence simply does not support the more extravagant claims about the "buying' of the Congress."); Larry Sabato, Real and Imagined Comuption in American Campaign Financing, in ELECTIONS AMERICAN STYLE 155, 160 (A. James Reichley ed., 1987) (noting that "most congressmen are not unduly influenced by PAC money on most votes").

${ }^{83}$ See Bruce Cain, Moralism and Realism in Campaign Finance Reform, 1995 U. CHI. LEGAL F. 111, 116 (1995) (arguing that campaign contributions are merely a means to the goal of getting elected and that votes are more crucial than money).

${ }^{84}$ On a personal level, for many years I have been associated with a variety of public policy think tanks, and I currently sit on the Board of Trustees of one such institution. Never have I known any of these groups to take a position, or to avoid taking a position, in order to please or to avoid offending donors. To the contrary, I have frequently seen them take stands that incur the wrath of donors and cause major declines in donations. In my role as a trustee, the only time I have seen the questions of donors even come up is when discussing either how to inform the donor of the position the organization intends to take, or when discussing how to convince the donor that he or she should continue to contribute to the organization. I believe that this is how most 
Consider just what it would mean for a legislator to act in a "corrupt" manner. For centuries, philosophers, political scientists, and others have debated how a legislator ought to make decisions. Suffice it to say that there is no consensus on the issue. Let me suggest, then, a few ways of decision making which, I think, have enough legitimacy that even those who disagree with them would not suggest that they are "corrupt."

First, a U.S. congressperson or senator might choose to act according to the desires of a majority of his constituents, whether or not doing so comports with his own best judgment. ${ }^{85}$ Second, he might choose to act according to his own best judgment and ideological principles, whether or not doing so comports with the wishes of his constituents. $^{86}$ This would be a legitimate method of acting whether the legislator is measuring the benefits according simply to what is best for his constituents, or whether he is considering what is best for the nation as a whole. These do not exhaust the possibilities for legitimate legislative action. A legislator might also legitimately (i.e., non- "corruptly") act in a way opposed to both her own best judgment and opposed to the desires of a majority of her own constituency. For example, if the legislator thinks it would be a good idea to allow private discrimination against homosexuals in the rental housing market, and recognizes that a majority of her constituents hold a mild preference for allowing such private discrimination against homosexuals, she might still act in support of a law barring such discrimination because of the much more intense preference of a minority of constituents who favor such legislation. This, too, I think is a legitimate mode of legislative action.

Which theory is best is, of course, a question for another day. At this point it is enough to note that a vote cast along any of these three lines cannot really be called "illegitimate" or "corrupt." In practice, I

of the professors who write on "reform," and most of the staffers and board members of advocacy groups which champion more regulation, conduct their affairs as well. It strikes me as odd, if not offensive, that these people assume that most members of Congress are feckless suits, easily swayed by a few dollars to their campaign organizations, while they themselves are men and women of principle. Nor have I felt that this created a difficult conflict of interest problem.

${ }^{85}$ See John Stuart Mill, Considerations on Representative Government, in THREE ESSAYS 143, 323 (Oxford ed. 1975) (noting that some representatives "feel bound in conscience to let their conduct, on questions on which their constituents have a decided opinion, be the expression of that opinion rather than of their own").

${ }^{86}$ See Edmund Burke, The English Constitutional System, in REPRESENTATION 157, 175 (Hanna Fenichel Pitkin ed., 1969) (stating that although the opinion of constituents is "weighty and respectable," the notion that a representative is "bound blindly" to obey is "unknown" to the law"). 
suspect that most legislators are frequently torn between these theories, and will usually vote their best judgment unless it means probable electoral defeat, or, conversely, will usually vote with the constituency unless the legislators hold very strong opinions to the contrary.

In any case, to find "corruption," we must assume that the representative is acting against his own best judgment and principles, against the wishes of a majority of his constituents, and against the intense preferences of a minority of his constituents, and that he is doing so in order to gain a campaign contribution (as opposed to a media or other endorsement, favorable press coverage, or some other electoral advantage). How likely is any legislator to do such a thing for a mere contribution? Yet people express surprise that empirical studies fail to show monetary contributions exerting much influence.

This is not to say that money never plays a role, or that monetary contributions may not weigh on the representative's mind. ${ }^{87}$ And, indeed, this simple observation defines a more subtle corruption thesis advanced by Professor Lowenstein. Professor Lowenstein argues that the fact that donor wishes will be just one factor among many in a legislator's decision-making process is the problem, and is what makes the role of money so insidious. It is not necessary for money to "corrupt" legislators in any outright way. Rather, the mere fact that it is there, influencing the "chemistry" or "mix" of the legislator's actions, "taints" the legislative process. ${ }^{88}$ For Professor Lowenstein, this inability to pinpoint the corruption is the clinching argument for doing away with private financing. The system cannot be policed because none of us-not even the legislators-can know the exact influence of contributors.

But if the wishes of contributors are just one factor among many, why do they "taint" the process any more than the fact that the legislator might consider the opinions of family, friends, or staffers; endorsements by newspapers, colleagues, and key constitutents; the information provided by lobbyists or groups which have not made contributions; and any of the other factors that might come into play?

One answer (apparently not Lowenstein's) is that money is "completely unrelated to the value of the idea it propels," whereas other influences "attract the candidate's attention because they are in a posi-

${ }^{87}$ See Ortiz, supra note 60 , at 899 ( $[$ [C]andidates [might] become so beholden to contributors that they follow the contributors' rather than the voters' interests. Everyone, including the Supreme Court, agrees that this is a serious danger. The pivotal questions concern how great a danger it actually presents ....").

${ }^{8 s}$ Lowenstein, supra note 18 , at 325-26. 
tion to persuade voters or to deliver blocks of votes. ${ }^{\text {,99 }}$ But this is not really the case. The spouse's position in the bedroom and ability to gain a legislator's ear may also be "unrelated to the value of the idea it propels." Staffers and friends are not in positions to "persuade voters or deliver blocks of votes" any more than most contributors. Newspaper and other endorsements are typically decided by a small group of individuals, who then try to persuade voters of the candidate's merit, and are in that respect little different than contributions, which are given to the candidate by a voter or voters so that the candidate can directly try to persuade other voters of the candidate's merit. Clearly the problem is not that money is any more "tainting" than are many of the other factors that go into decision making, and that, in any event, are secondary to the dominant, "untainted" considerations of ideology and constituency desires.

Professor Lowenstein's answer, and apparently Professor Briffault's, is that this low-level monetary influence is inappropriate simply because our culture regards it as inappropriate. ${ }^{90}$ The potential influence of money is a problem because, among forms of political influence, we consider money a unique problem. He argues that scholars such as myself "would not be at such great pains to characterize the influence of campaign contributions as minimal if they did not believe that it would be wrong if the contributions were influential, or at least that the overwhelming majority of their fellow citizens believe that it would be wrong. ${ }^{91}$ I disagree. We are at pains to show that the influence of contributions is minimal-in the sense that they might lead to the quid pro quo corruption that Buckley held to be the constitutional justification for limits and that most citizens find abhorrent-precisely because if we show that contributions do not lead to rampant quid pro quo corruption, we believe that the majority of our fellow citizens will not be concerned about campaign contributions or find them problematical. And the placidity with which citizens react to reform proposals, so-called scandals, and proposals for government financing is evidence of that fact. ${ }^{92}$ The fact is, the American people have proven

${ }^{89}$ Rosenkranz, supra note 69 , at $894-95$.

${ }^{90}$ See Lowenstein, supra note 18, at 328-29 (describing campaign contributions as "payments of money to the official for the official's benefit" and concluding that this is the "paradigm case for improper influence").

91 Id. at 329.

${ }^{92}$ See Investigation of Illegal or Improper Activities in Connection with the 1996 Federal Election Campaign-Pant VII: Hearings before the Senate Comm. on Governmental Affairs, 105th Cong. 400 (1997) (statement of Curtis Gans, policy analyst) [hereinafter Investigation of 1996 Elections] (discussing public disinterest in campaign finance "scandals," 
time and time again that they are not particularly disturbed by the way in which campaign funds are raised and the minor role that they might play in legislative behavior.

Professor Lowenstein then adds that our culture regards any role for private money as inappropriate because "it constitutes bribery, as that crime is defined in most American jurisdictions. ${ }^{\text {"93 }}$ I doubt, however, that any state enacted its bribery statute with campaign contributions in mind. In any case, as Professor Lowenstein notes, campaign contributions are rarely prosecuted under such laws. He attributes this to the pervasiveness of the practice, rather than to approval of the process. ${ }^{94 .}$ I attribute it to the fact that no more than a very small minority of Americans really consider private contributions to be bribery, and that there is no more a cultural norm against the practice than there is a cultural norm against driving 68 miles per hour in a 65 mile per hour zone.

Thus, I cannot agree with Professor Lowenstein's assertion that:

It is a fact of our political culture that although a great variety of the pressures brought to bear on politicians embody forces that are regarded as more or less democratic and therefore legitimate, this is not true of pressure imposed by payments of money to politicians, either for their personal benefit or for campaign use.

To the contrary, I believe that our political culture does not consider a contribution for campaign use to be corrupting, which is why campaign finance reform has never become an important issue with the voting public, and which is why millions of American citizens make campaign contributions and never feel the least tainted by the process. Indeed, my own observation is that politicians often find it easier to tell a constituent that his vote was dictated by campaign contributions than to admit that it was dictated by disagreement with the

and concluding "the American people understand that it takes money to run political campaigns and that, in the absence of total public financing of such campaigns, candidates are going to, and should, solicit funds for those campaigns"); Smith, supra note 24, at 833-36 (noting that public opinion polls reveal the public's ambivalence on the issue of campaign finance reform); The Tarrance Group, Key Findings from a Nationwide Survey of Voter Attitudes About Campaign Finance Reform (visited Oct. 18, 1999) <http://www.tarrance.com/polls/campfin.htm> (finding that $78 \%$ of respondents oppose tax funding of campaigns).

${ }^{93}$ Lowenstein, supra note 18, at 329. See generally Daniel H. Lowenstein, Political Bribery and the Intermediate Theory of Politics, 32 UCLA L. REV. 784, 808-09, 826-28 (1985) (opining that most campaign contributions constitute bribes).

${ }^{94}$ See Lowenstein, supra note 18 , at 329.

${ }^{95}$ Id. 
constituent. That strongly suggests that there is not a strong cultural norm against the influence of contributors, even when that influence is described in terms that indicate "corruption" far more strongly than Professor Lowenstein's idea of a "tainted" system.

It is probably true that it is rare for a legislator to admit that contributors influenced his activity, but it is, I believe, equally rare for a legislator to admit that the possibility of a newspaper endorsement, or even the endorsement of a powerful group representing large numbers of members, influenced his activity. ${ }^{96}$ So the opinions of donors go into the mix, along with the opinions of numerous other individuals whose influence sometimes does and sometimes does not have anything to do with their numbers, their talents, or some third party's view of the merit of their opinions.

Most Americans are sophisticated enough to recognize that these donors usually represent large numbers of persons with similar views, and when they do not, it is perhaps even more important that they be heard. Indeed, in some cases it will be a good thing for the representative to overtly consider donations, as monetary contributions can be an indicator of the intense preferences of a minority, or of the preferences of the majority. Given all this, I am simply not persuaded that this influence-and this type of influence alone-is so corrupting that it calls for limiting a primary mechanism, and in many cases the only real mechanism, for millions of Americans to participate in the political system.

At this point we are told that even if all that I have written is true, the political system is "corrupt" because some have more "access" than others. This is not entirely true. The fact is, the vast majority of campaign contributors never seek access, and legislators meet regularly with people who have never made contributions. Nor does every contributor who seeks access get it. ${ }^{97}$ To the extent that the access theory is true, however, I am not exactly certain why this should shock me. For one thing, such contributors are often well informed on public issues and provide valuable information to representatives. But beyond that, I think we are back to the romantic notions of political life that surface in the equality debates. There seems to be a notion that

${ }^{96}$ How often do you hear a Democrat say that he thinks minimum wage increases are a bad idea, but votes for them anyway just to keep labor unions happy? Or even that the prospect of getting labor's vote influenced his decision?

${ }^{97}$ See Hearings on Campaign Contribution Limits, supra note 81 , at *6 (testimony of former Senator Dan Coates) ("A contribution is by no means necessary to obtain a meeting, and a meeting by no means guarantees results."). 
but for monetary contributions, the typical congressional representative would ... well, would what? Randomly call citizens in his district to get their opinions? ${ }^{98}$ Or spend more time golfing? The most likely result, I think, is that the typical representative would spend more time with the people who already surround him most of the day, and who make up the single largest group of witnesses in congressional committee hearings: other government employees and officials. Personally, I would rather see him or her get out and spend some time with private sector lobbyists. ${ }^{99}$ But if private contributions were banned, there are two things of which we can be absolutely sure: the overwhelming majority of citizens would still never, ever, get to spend even two minutes discussing public affairs with their congressional representatives; and the number of private citizens with whom that representative does discuss public affairs would almost certainly decline.

\section{THE FUTILITY OF GOVERNMENT FINANCING}

So, are we left at a draw? Either you subscribe to the Platonist theory of political equality or you do not; either you find the anticorruption rationale (which by definition cannot be disproven) persuasive, or you do not. Despite the disadvantages to government financing pointed out in Part I, I suspect that most people who fall into the former categories-that is, who accept Platonist thinking or who still fear corruption, however improbable-will still favor government financing.

There is, however, one more issue to address, and having written so much prose, it seems almost perverse to disclose it now. Nevertheless, here it is: even with a major change in constitutional jurisprudence (probably requiring a constitutional amendment), government financing will not solve either the equality or the corruption problems.

We have $100 \%$ government financing, with voluntary spending limits, of the presidential general election campaigns now. No major party nominee has ever opted out of the system or broken the expen-

${ }^{93}$ Imagine the probable results of such phone calls. I expect that there would be a large number of hang-ups, many more "I don't knows," and a great deal of off-the-cuff advice by persons with little knowledge of the issues the representative may be addressing. In general, it would be time poorly spent.

${ }^{9}$ Others might not, but I see no reason why they should impose their theory of good government on my representative! 
diture limit. ${ }^{100}$ Yet, those who demand more regulation, in this case those who favor extending some type of tax financing to congressional and senatorial campaigns, do not generally consider the presidential system to have even remotely resolved the problems of equality or corruption. The reason is simple: the primary result of public funding of presidential campaigns has been to distort political campaigns and cause monetary participation to take new forms. In particular, the successful effort to chop off the head of "evil" in presidential campaigns-private donations to candidates-has caused the Hydra-like growth of the twin "evils" of "soft" money and "issue advocacy," which would-be regulators now denounce. ${ }^{101}$ Thus, candidates' campaigns do not spend money, yet money is spent, on independent expenditures, issue ads, convention sponsorship, party-building activities financed with soft money, and more. "Soft" money and "issue advocacy," to focus only on the two most disparaged evils, cannot be successfully regulated for both practical and constitutional reasons. ${ }^{102}$

Even if proposals to regulate "soft" money and "issue advocacy"

${ }^{100}$ Candidates, including George W. Bush and Steve Forbes, have opted out of the primary system, but no major party nominee has opted out of public funding in the general election.

${ }^{101}$ For a description of "soft" money and its evils from the perspective of an avid partisan for banning soft money, see Donald J. Simon, Beyond Past-Watergate Reform: Putting an End to the Soft Money System, 24 J. LEGIS. 167, 177 (1998). For a recent discussion of issue ads, again from a pro-regulation standpoint, see Richard Briffault, Issue Advocacy: Redrawing the Elections/Politics Line, 77 TEx. L. REv. 1751 (1999).

102 The Supreme Court's key decisions on the right to engage in "issue advocacy" are Buckley $v$. Valeo, 424 U.S. 1, 79-80 (1976) (restricting permissible regulation to funds spent in concert with a candidate to advocate election or defeat of a clearly identified candidate), and Federal Election Comm'n v. Massachusetts Citizens for Life, Inc., 479 U.S. 238, 253-54 (1986) (distinguishing Massachusetts Citizens for Life from PACs because its purpose is issue advocacy rather than the nomination or election of a candidate). Recent efforts to regulate "issue advocacy" within the constraints of Buckley have been uniformly struck down by the courts. See James Bopp, Jr., Campaign Finance "Reform": The Good, the Bad, and the Unconstitutional, HERTAGE FOUND. BACKGROUNDER (Heritage Foundation, Washington, D.C.), July 19, 1999, at 1 (citing 20 federal cases that have "adhered faithfully to the 'explicit' or 'express' words of the advocacy test according to its plain terms"). The Court has never explicitly ruled on efforts to ban soft money but has implicitly indicated that most soft money cannot be regulated in accordance with the Constitution. See Bopp, supra, at 7 (noting that the Court has found that proposed bans on political parties' receiving soft money cannot be justified by the government's interest in preventing corruption); Gora, supra note 73, at 161 (noting that there is "not a word in Buckley" that suggests that the Court would uphold a total ban on PACs and soft money); Smith, supra note 54, at 182-83 (noting that the Buckley court suggested that ads which did not urge the election or defeat of a candidate could not be constitutionally subjected to regulation); see also Issacharoff \& Karlan, supra note 19, at 1708-17, 1735-36 (discussing both practical reasons and general constitutional principles that make regulation unlikely to succeed). 
were to be upheld against constitutional challenge in the courts-or perhaps implemented after constitutional amendment ${ }^{103}$-this would not solve the regulators' dilemma. There are simply too many ways for those who want to influence public policy to do so. For example, in 1996 the Republican and Democratic parties spent nearly $\$ 41$ million on their national conventions, although only $\$ 8$ million was provided in federal funds for the conventions. The extra money came in the form of corporate sponsorship for "civic and commercial" purposes. ${ }^{104}$ In fact, such sponsorship both helps the conventions work as part of the campaign (by firing up activists and drawing added paid and free media attention) and provides a method for donors interested in supporting candidates and parties to do so.

Convention sponsorship is an obvious way of rerouting political spending in a world of spending caps. Even if soft money and issue ads could be constitutionally regulated, many other approaches would spring up, perhaps including the purchase of partisan media outlets. Thus, extreme proposals now favor curbing the ability of the press to make political endorsements. ${ }^{105}$ Even these proposals, if enacted under an amended constitution (almost certainly a necessity), would not solve the "problem" because the main complaint with the influence of the press is not over its overt editorializing but rather over its coverage and selection of news. ${ }^{106}$ There are numerous other ways to sidestep even these draconian types of regulation. With a federal government that currently spends over $\$ 1.5$ trillion per year and which claims the right to regulate local education, virtually every phase of the employer-employee relation, prices, wages, gun ownership, birth control, tobacco use, drug use, foreign trade, health care, and much, much more, there is no reason to think that those who seek to influence who holds power in this monumental government will not be creative enough to circumvent the regulations. ${ }^{107}$

${ }^{103}$ Such a resolution was introduced and voted on in the 105th Congress. See H.R.J. Res. 47, 105th Cong. (1997).

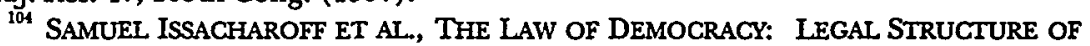
THE POLITICAL PROCESS 660-61 (1998).

${ }^{105}$ See Foley, supra note 66, at 1252 (advocating a rule which would "prohibit newspapers from using their resources to publish editorials that support or oppose a candidate or ballot initiative"); Hasen, supra note 58, at 1665 ("[P]olitical equality will be limited so long as the media are exempt from otherwise applicable campaign finance regulations.").

${ }^{106}$ See L.A. Powe, Jr., Boiling Blood, 77 TEx. L. REV. 1667, 1670 (1999) ("The influence of the press comes from its choices of coverage: which stories (or issues) and how presented (including photography).").

${ }^{107}$ See Bradley A. Smith, The Sirens' Song: Campaign Finance Regulation and the First 
Of course, a system that makes participation harder, and perhaps less effective, may eventually reduce or eliminate such participation. After all, if issue ads had to be run at least sixty days before an election-a currently popular proposal-they may not be as effective, resulting in a decline in their use. One who is convinced that federal representatives are easily bought and purchased, or one who favors the Platonist concept of political equality, may find this a worthwhile endeavor.

I think, rather, that our experience with campaign finance laws indicates that any number of things could go wrong with this manner of reform. Making such political activity less effective may just increase the amount of it in order to achieve the same results. It may lead to the creation of other advertising means that can affect federal elections-indeed, wherever the line on express advocacy is drawn, it will not be hard for political operators to stand at the edge of the new line. Restrictions on private financing may increase the influence of groups with a strong, permanent presence in Washington, rather than increasing the influence of more decentralized groups that rely on a large membership base and a PAC funded by small contributions. Such restrictions might also inhibit the arrival of a well-financed hero to channel their energies, much as large contributions to the Gene McCarthy campaign in 1968 brought together disparate, scattered anti-war sentiments into a meaningful, anti-Vietnam War political campaign. This is particularly true if, as with the McCarthy campaign, key issues come to the fore too late for a would-be candidate to comply with the government financing scheme. Restrictions may simply drive expenditures further underground.

In short, where the editors' proposition goes most wrong is when it says, "including voluntary spending limits." tary" spending limit comes when those who care about politics decide not to spend any more-everything else is a coercive limit on political speech, else it need not be included in the law. Because the limit is not voluntary, and because we have a First Amendment allowing free discussion of political issues, a way will be found around that limit. So long as this is the case, the goal of "reduc[ing] the political influence of special interests, ${ }^{\text {p109 }}$ whether we define that influence as creating an

Amendment, 6 J.L. \& POL'Y 1, 28-41 (1997) (noting that there will always be loopholes and that the potential for corruption will always exist).

${ }_{109}$ Election 2000: Point / Counterpoint Series, 148 U. PA. L. REV. 561, 561 (1999).

${ }^{109}$ Id. 
"equality" problem or a "corruption" problem, is not going to be met merely through government financing.

\section{CONCLUSION}

Government subsidies of political campaigns, if not tied to bans on private contributions and spending limits, may indeed have certain benefits for political life. ${ }^{110}$ A well-designed system might increase competitiveness, and therefore accountability, and it might also increase the flow of information to voters as well as the availability of well-qualified candidates. For reasons discussed in Part I, I tend to be skeptical that such a well-designed system could be enacted or maintained. ${ }^{111}$ In any case, such a system is probably off the charts politically: none of the major "reform" groups seems willing to even consider a government funding proposal that does not include limits on contributions and spending."

Government financing plans which include limits on contributions and spending, whether deemed "voluntary" or not, are doomed to failure. The United States was well served by the totally deregulated system that existed prior to this century and by the largely deregulated system that existed prior to the passage of FECA in 1974. Even with the distortive effects that FECA has had on the political scene, the United States remains one of the healthiest democracies, despite, or perhaps because of, its reliance on private financing of campaigns.

Rather than rethink our historic opposition to governmentfinanced campaigns, perhaps it is time for self-styled reformers to rethink their opposition to deregulated campaigns.

${ }^{110}$ See Gora, supra note 73, at 184-86 (arguing that meaningful public subsidies and funding of candidates and campaigns will facilitate political opportunity and participation).

${ }^{111}$ It is beyond the scope of this Article, but I share many of the concerns of those who argue that tax financing of political speech is at its core morally wrong. See Thomas Jefferson, A Bill for Establishing Religious Freedom, in THE PORTABLE THOMAS JEFFERSON 252 (Merrill D. Peterson ed., 1975) (“[T]o compel a man to furnish contributions of money for the propagation of opinions which he disbelieves and abhors, is sinful and tyrannical ...."). I also share the concerns of many who consider it bad policy to have politicians more beholden to the government for their campaign funding than to their fellow citizens.

${ }^{112}$ The only significant group of which I am aware that has consistently urged such an approach is the American Civil Liberties Union. See AMERICAN CIVIL LIBERTIES UNION, POLICY GUIDE 75-77 (1993). 